\title{
Impacts of Beijing Bus Rapid Transit on Pre-owned Home Values
}

\author{
Hao Pang and Junfeng Jiao \\ University of Texas at Austin
}

\begin{abstract}
Bus Rapid Transit (BRT) has gained increasing popularity worldwide in the last few decades. However, few studies have investigated BRT's impacts on property values in Chinese cities. This research, taking BRT route 1 (BRT1) and BRT route 3 (BRT3) in Beijing as examples, showed that proximity to BRT3 stops is weakly related to pre-owned home prices along the route, whereas BRT1 has induced a significant price premium. For BRT1, the impact is not linear. Specifically, pre-owned home prices for homes within 5-10 minutes' walking distance to BRT stations is $5.35 \%$ higher than those located closer to or farther away. The difference between the two routes can be explained by resident income differences and BRT route alignments. For homes very close to the subway route, the impacts of BRT vanish.
\end{abstract}

\section{Introduction}

Bus Rapid Transit (BRT) has gained increasing popularity worldwide in the last few years. Advanced and mature BRT services can be found in many cities in the world, such as Bogotá (Colombia), Curitiba (Brazil), Clermont-Ferrand (France), Orlando (U.S.)., Cleveland (U.S.), Adelaide (Australia), Brisbane (Australia), Osaka (Japan), etc. Historically, BRT has played a more important role in the urban development of developing countries, especially in Latin America. The success of introducing BRT services to these countries mostly stems from the dedicated lanes that offer shorter traveling time compared with traditional bus transit (Vuchic et al. 2014). The Institute for Transportation and Development Policy (ITDP) (Wright and Hook 2007) described BRT as a good alternative public transit mode in terms of relieving traffic congestion, reducing carbon emissions, saving commuting costs, and attracting development along the route. In the United States, the development of BRT projects has been spurred by the Federal Transit Administration's (FTA) BRT initiative (Lee, Miller, and Skinner 2007).

In China, BRT is an emerging idea. The first BRT line in China was built in Beijing in 2006. Since then, many other cities began to consider BRT as an important alternative means of public transit to significantly reduce city infrastructure cost, traffic congestion, and carbon emissions. However, to the authors' knowledge, compared to other public transit 
modes, few studies have investigated BRT's impacts on surrounding residential property values in Chinese cities.

This research investigated whether the proximity to BRT routes and the surrounding built environments around BRT stops has impacted property values in Beijing. The next section reviews the effect of public transit on property values and several relevant research topics associated with BRT. This is followed by information on sites, data, variables, and methodology applied in this paper. Finally, results from the Hedonic Model are discussed, as are key findings and their implications.

\section{Literature Review}

Many studies have investigated the impacts of transit-oriented development (TOD) on surrounding property values and reported positive results (Garrett 2004; McMillen and McDonald 2004; Weinstein et al. 2014; Cervero and Duncan 2004; Haider and Miller 1995; Knaap, Ding, and Hopkins 2001). Of these studies, Chicago's Midway Line showed that the opening of new rail services increased housing prices, with rates of land-value appreciation varying over time (McMillen and McDonald 2004). However, some studies produced the opposite results (Landis, Guhathakurta, and Zhang 1994; Celik and Yankaya 2006). One study in San Francisco found that rail-based TOD had a positive impact on downtown commercial properties but showed no impacts on suburban commercial properties (Cervero and Landis 1997). Although they measured accessibility and nuisance effects, some scholars did not report any positive impacts (Landis, Guhathakurta, and Zhang 1994; Gatzlaff and Smith 1993). Garrett (2004) found that the nuisance impacts on rents were modest and only accessibility, which was measured by distance to the nearest station, was valued, whereas service nuisance, measured by distance to the service corridor, was not significant.

For bus services, it is easy to understand that their impacts on spatial form and land use patterns are limited because, in contrast to many rail systems, it is difficult for buses to provide any appreciable accessibility benefits, and high use of private vehicles makes this benefit negligible (Cervero and Kang 2011). Cao and Hough (2012) found that in North Dakota, buses had no significant impact on land value. The impact was even negative within $200 \mathrm{~m}$ of a bus stop.

Compared to rail and bus, fewer studies have examined the impact of BRT on properties. Levinson et al. (2002) reported that the land-use benefits of BRT were as significant as LRT in Brisbane. The studies of the BRT system in Bogotá (Rodríguez and Targa 2004) also showed appreciable land value benefits. Rodriguez and Mojica (2008) found that for residences that already had benefited from the service in 2000, housing prices increased, on average, by $15-20 \%$. In addition, Cervero and Kang (2011) found that in Seoul, within 300 $\mathrm{m}$ buffers of BRT stops, $10 \%$ of the residential house premiums resulted from BRT service. However, for some areas where BRT services were not well-managed or lanes were confined by urban spatial form or local policy, no significant impacts of BRT on land values were observed (Vuchic 2002; Cervero and Duncan 2004).

As the first city in China to build a BRT lane, Beijing has plans to gradually establish a BRT network system to complement the existing light rail system. The main purpose is to connect all major centers within the city limits and provide a good mode for people to 
visit important suburban centers. Beijing's first BRT was constructed in 2006. Currently, there are four main lines and three branch lines. According to Beijing's BRT Network Plan (2008-2020) (Yang and Xiangzhao 2010), the $1.5 \mathrm{~km}$ buffer area surrounding BRT stations within the city center will cover $85 \%$ of the total city area, and the $500 \mathrm{~m}$ service area will cover $50 \%$ of the population within the city center by 2020 . Based on the authors' knowledge, few studies have investigated the impacts of BRT on property values in China. Therefore, analyzing the impact of Beijing's BRT system on property values is important, both theoretically and empirically.

\section{Site and Data}

This research focused on Beijing's two earliest routes in operation, BRT route 1 (BRT1) and BRT route 3 (BRT3) (Figure 1). Without complete and instant real estate data from public institutes such as Bogota's Department of Housing Control (DHC), various challenges arise in terms of collecting historical data for the transaction price of a specific property in China. In this research, we collected market prices for second-hand residential properties that were sold between April and May of 2012 from the database of China's largest real estate website, Soufun.com. After removing records with uncertain information, 554 sales records were collected. Among them, 272 records were along BRT1 and 282 were along BRT3 (see Figure 2).
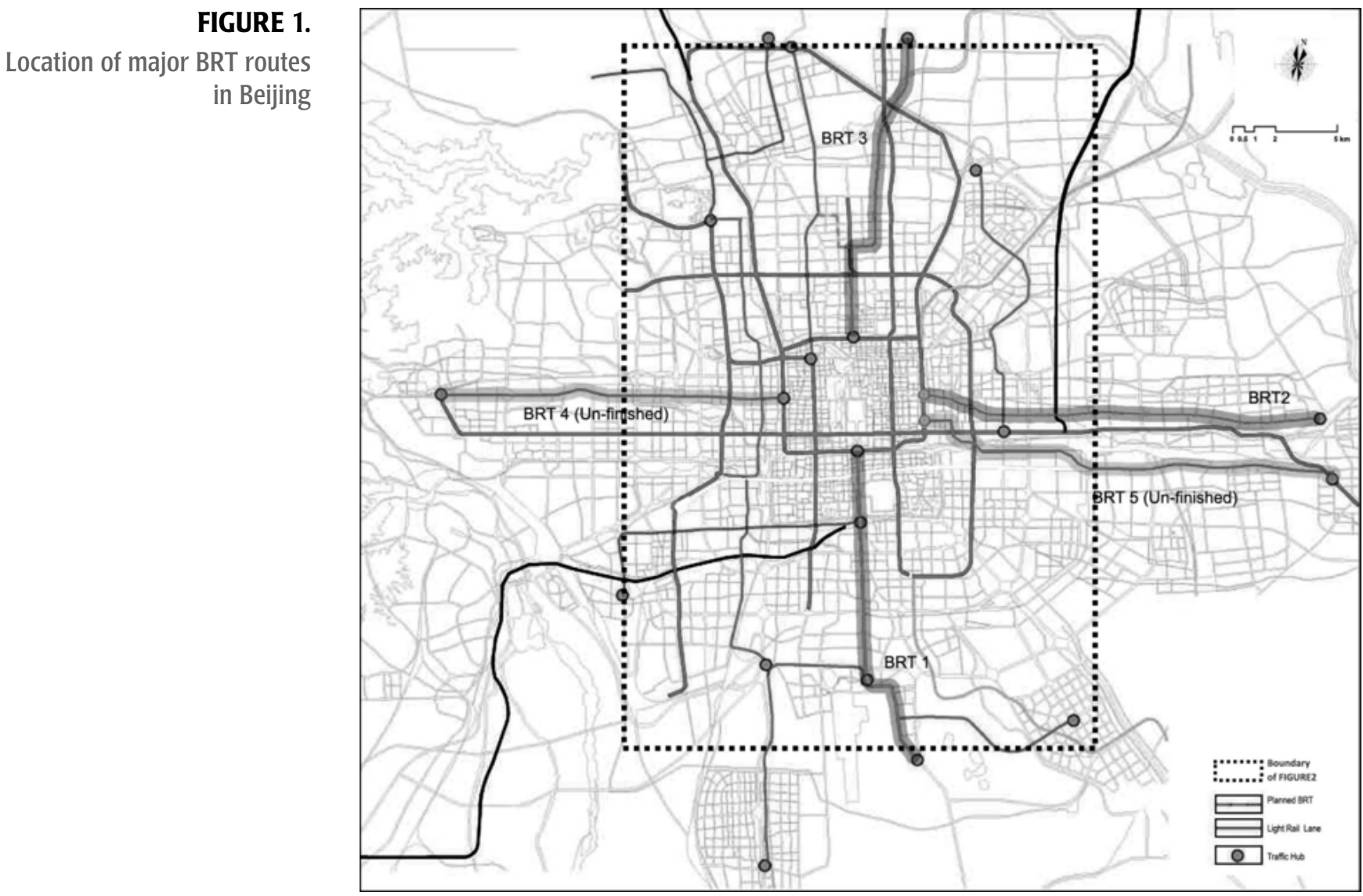

Source: Yang and Xiangzhao 2010 
FIGURE 2.

Sample

residential sale

locations along

BRT1 and BRT3,

Beijing, April-

May 2012

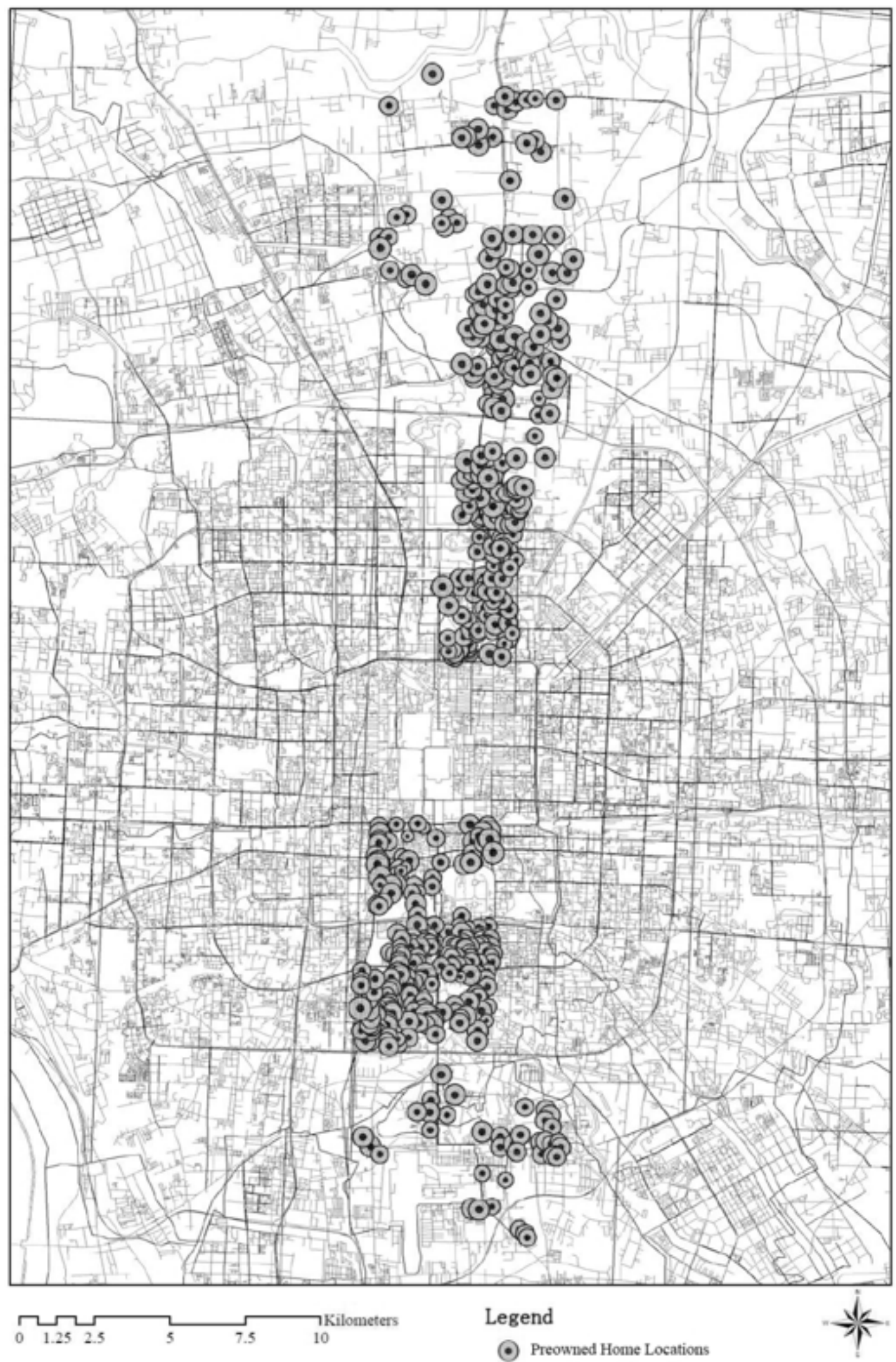


Since this study focused on how BRT influences pre-owned home prices, it is reasonable to include only dwellings close to BRT stations instead of an entire region. According to Munoz-Raskin (2010), pedestrians can bear walking without too much physical burden for no longer than 10 minutes. Knoblauch et al. (1996) showed that people can walk as far as 822 meters within 10 minutes. This research focused on people who can access a BRT station even if they may feel a little bit uncomfortable. Neighborhoods located within a 20-munite walking distance (1,644 meters) from a BRT station were taken into account in this study. Table 1 shows variables and data sources used by this research.

TABLE 1. Variables and Measurements

\begin{tabular}{|c|c|c|}
\hline & Description & Measures \\
\hline \multicolumn{3}{|l|}{ Dependent Variables } \\
\hline $\mathrm{P}$ & Price of second-hand residential properties sold April-May 2012 & $\mathrm{RMB} / \mathrm{m}^{2}$ in 2012 \\
\hline \multicolumn{3}{|l|}{ Independent Variables } \\
\hline \multicolumn{3}{|l|}{ Dwelling Characteristics } \\
\hline Dwelling size & Area of dwelling unit $\left(\mathrm{m}^{2}\right)$ & $\mathrm{m}^{2}$ per unit \\
\hline Gross floor area & $\begin{array}{l}\text { Total floor area inside building envelope, including external walls and excluding } \\
\text { roof }\end{array}$ & $\mathrm{m}^{2}$ \\
\hline Lot area & Total area of lot where building located & $\mathrm{m}^{2}$ \\
\hline Floor area ratio (FAR) & Ratio of gross floor area to lot area & ratio \\
\hline Green area ratio (GAR) & Ratio of area of landscape elements to lot area & ratio in $100 \%$ \\
\hline $\begin{array}{l}\text { Number of dwelling units per } \\
\text { neighborhood }\end{array}$ & Number of dwelling units per neighborhood & Counts \\
\hline Dwelling age & 2012 minus years (commenced) & Year \\
\hline Building height & Number of stories & Number of stories \\
\hline Slab type apartment & Tower apartment: 0 Slab (block) apartment: 1 & Category \\
\hline Finely decorated apartment & $\begin{array}{l}\text { Roughcast: } 0 \text { (no furniture included, wall and floor roughly painted without } \\
\text { wallpaper, carpet or ceramic tile); Fine decorated: } 1 \text { (room may have basic } \\
\text { furniture, wall finely painted or wallpapered, carpet or ceramic tile included) }\end{array}$ & Category \\
\hline \multicolumn{3}{|l|}{ Facility Accessibility } \\
\hline Good accessibility to primary stores & Number of primary stores within $805 \mathrm{~m}(1 / 2 \mathrm{mi})$ & Counts \\
\hline Good accessibility to schools & Number of schools within $805 \mathrm{~m}(1 / 2 \mathrm{mi})$ & Counts \\
\hline $\begin{array}{l}\text { Good accessibility to health care } \\
\text { facilities }\end{array}$ & Number of hospitals or clinics within $805 \mathrm{~m} \mathrm{(1/2 \textrm {mi } )}$ & Counts \\
\hline \multicolumn{3}{|l|}{ Distance Attributes } \\
\hline Distance to city center & Straight distance to city center, Tiananmen Square $(\mathrm{m})$ & $\mathrm{m}$ \\
\hline Distance to nearest subway station & Straight distance to nearest subway station $(\mathrm{m})$ & $\mathrm{m}$ \\
\hline Distance to nearest rapid bus station & Straight distance to nearest rapid bus station $(\mathrm{m})$ & $\mathrm{m}$ \\
\hline $\begin{array}{l}\text { Less than } 5 \text { min to nearest rapid bus } \\
\text { station on foot }\end{array}$ & Within 5 min walking distance from nearest rapid bus station Yes: 1 No: 0 & Category \\
\hline $\begin{array}{l}\text { Less than } 10 \text { min but longer than } 5 \mathrm{~min} \\
\text { to nearest rapid bus station on foot }\end{array}$ & Within 5-10 min walking distance from nearest rapid bus station Yes: 1 No: 0 & Category \\
\hline $\begin{array}{l}\text { Longer than } 10 \text { min to nearest rapid } \\
\text { bus station }\end{array}$ & Within 10-15 min walking distance from nearest rapid bus station Yes: 1 No: 0 & Category \\
\hline
\end{tabular}


In this study, three types of attributes were considered: dwelling characteristics, facility accessibility, and distance. Descriptive statistics for all variables are shown in Table 2. Two important differences between BRT1 and BRT3 are 1) the average selling price of pre-owned homes along BRT3 was 2,000 RMB (325 USD), which is more expensive than those near the BRT1, and 2) samples along BRT3 were closer to both subway and rapid bus stations but had poor accessibility to primary stores, schools, and hospitals.

TABLE 2. Descriptive Statistics

\begin{tabular}{|c|c|c|c|c|c|c|}
\hline \multirow{2}{*}{ Variables } & \multicolumn{3}{|c|}{ Homes along BRT1 } & \multicolumn{3}{|c|}{ Homes along BRT3 } \\
\hline & Mean & Max & Min & Mean & Max & Min \\
\hline \multicolumn{7}{|l|}{ Continuous Variables } \\
\hline$P\left(R M B / m^{2}\right.$ in 2012$)$ & 24276.00 & 52933 & 11391 & 26015.55 & 71548 & 7485 \\
\hline Dwelling size ( $\mathrm{m}^{2}$ per unit) & 92.35 & 370 & 15 & 123.52 & 650 & 38.0 \\
\hline Gross floor area $\left(\mathrm{m}^{2}\right)$ & $155,698.50$ & $1,200,000$ & 1342 & $189,610.60$ & $2,300,000$ & 5,000 \\
\hline Lot area $\left(\mathrm{m}^{2}\right)$ & $71,449.52$ & 663,000 & 590 & $104,829.30$ & $1,040,000$ & 1,000 \\
\hline FAR & 2.54 & 12 & 0.34 & 2.71 & 14 & 0.2 \\
\hline GAR (\%) & 31.8 & 75.0 & 10 & 35.2 & 85.0 & 16.0 \\
\hline Number of dwelling units per neighborhood & $1,406.52$ & 15,800 & 33 & $1,594.07$ & 10,000 & 30 \\
\hline Dwelling age (years) & 11.94 & 50 & 1 & 11.29 & 29 & 1 \\
\hline Building height (stories) & 11.47 & 33 & 3 & 13.87 & 33 & 2 \\
\hline Distance to city center (m) & $7,357.36$ & 16,043 & 2,142 & $10,700.11$ & 22,818 & 3513 \\
\hline Distance to nearest subway station (m) & $1,529.96$ & 7,767 & 92 & 935.15 & 4,597 & 80 \\
\hline Distance to nearest rapid bus station (m) & $1,305.35$ & 2,809 & 116 & 937.65 & 4,004 & 98 \\
\hline Categorical Variables & Yes & No & & Yes & No & \\
\hline Slab type apartment & $74.3 \%$ & & $25.7 \%$ & $64.5 \%$ & & $35.5 \%$ \\
\hline Fine decorated apartment & $76.1 \%$ & & $23.9 \%$ & $75.9 \%$ & & $24.1 \%$ \\
\hline Good accessibility to primary stores & $54.8 \%$ & & $45.2 \%$ & $28.7 \%$ & & $71.3 \%$ \\
\hline Good accessibility to schools & $74.6 \%$ & & $25.4 \%$ & $47.9 \%$ & & $52.1 \%$ \\
\hline Good accessibility to hospitals & $51.5 \%$ & & $48.5 \%$ & $48.6 \%$ & & $51.4 \%$ \\
\hline Less than $5 \mathrm{~min}$ to nearest rapid bus station on foot & $12.5 \%$ & & $87.5 \%$ & $19.1 \%$ & & $80.9 \%$ \\
\hline Less than $10 \mathrm{~min}$ but longer than $5 \mathrm{~min}$ to nearest rapid bus station on foot & $15.1 \%$ & & $84.9 \%$ & $35.1 \%$ & & $64.9 \%$ \\
\hline
\end{tabular}

\section{Methodology}

Hedonic models were employed to capture the impacts of proximity to BRT stations on pre-owned home values. Starting with three model specifications-semi-log, log-log, and Box-Cox-this study applied a log-log form model for the final models because of its better goodness of fit than semi-log and better economic meanings than the Box-Cox model.

A hedonic price model always faces a multi-collinearity issue, especially when it includes several geographic features (Palmquist 1991). In this research, a stepwise regression, an F test, and a likelihood ratio test were applied to determine and remove redundant variables. The model specifications are: 


$$
\ln \mathbf{P}=\alpha_{0}+\sum_{I} \beta_{i} \ln \mathbf{D} \mathbf{W}_{i}+\sum_{K} \delta_{k} \ln \mathbf{F} \mathbf{A}_{k}+\sum_{T} \lambda_{t} \ln \mathbf{D} \mathbf{S}_{t}+\sum_{J} \gamma_{j} \mathbf{D}_{j}+\varepsilon_{\text {robust }}
$$

Where,

$$
\begin{aligned}
& \mathrm{P}=\text { pre-owned home price } \\
& \mathrm{DW}_{\mathrm{i}}=\mathrm{i}^{\text {th }} \text { variable of Dwelling Characteristics } \\
& \mathrm{AC}_{\mathrm{k}}=\mathrm{k}^{\text {th }} \text { variable of Facility Accessibility } \\
& \mathrm{DS}_{\mathrm{t}}=\mathrm{t}^{\text {th }} \text { variable of Distance Characteristics } \\
& \mathrm{D}_{\mathrm{j}}=\mathrm{j}^{\text {th }} \text { dummy variable } \\
& \varepsilon_{\text {robust }}=\text { heteroscedasticity robust standard error }
\end{aligned}
$$

A hedonic price model assumes that a consumer's preference for each attribute is unsaturated. As stated, BRT can bring accessibility benefits to residents in the vicinity but also may result in problems such as nuisance and unfairness, both of which could have negative impacts on property value. One solution for saturated preference is to apply different dummy variables for specific ranges of distance instead of directly using distance as one variable. In this study, BRT accessibility was measured as 1) straight distance and 2) dummy variables set for specific ranges of distance.

\section{Results}

Our research showed that the following factors contributed to higher pre-owned home prices: 1) shorter distance to city center, 2) shorter distance to subway stations, 3) higher green area ratio (GAR), 4) newer property, 5) slab-type, and 6) smaller floor area ratio (FAR). Specifically, distance to the city center was the dominant impact for both BRT1 and BRT3. As shown in Table 3, a decrease of $1 \%$ in distance to city center could lead to a decrease of $0.47 \%$ in pre-owned home price for BRT1 and $0.65 \%$ for BRT3. Also, the pre-owned home price was significantly impacted by proximity to a subway station. An increase of $1 \%$ in proximity to a station increased the pre-owned home price by $0.064 \%$ for BRT1 and $0.11 \%$ for BRT3. The impact of facility accessibility was insignificant. One possible reason might be that, given that Beijing is the capital of China, facilities and other services can cover larger portions of the city compared to other cities in China, meaning that the accessibility to those facilities has relatively little impact on pre-owned home prices in comparison with dwelling characteristics and distance attributes. 
TABLE 3.

Summary of Model Estimation

\begin{tabular}{|c|c|c|c|c|}
\hline \multirow{3}{*}{ Independent Variables } & \multicolumn{2}{|c|}{ Homes along BRT1 } & \multicolumn{2}{|c|}{ Homes along BRT3 } \\
\hline & \multicolumn{4}{|c|}{ Distance Attributes estimated using: } \\
\hline & $\begin{array}{l}\text { Straight } \\
\text { distance }\end{array}$ & $\begin{array}{l}\text { Dummy } \\
\text { variables }\end{array}$ & $\begin{array}{l}\text { Straight } \\
\text { distance }\end{array}$ & $\begin{array}{c}\text { Dummy } \\
\text { variables }\end{array}$ \\
\hline \multicolumn{5}{|l|}{ Dwelling Characteristics } \\
\hline \multirow{2}{*}{ Dwelling size (square term) } & $0.0617^{* * *}$ & $0.0602^{* * *}$ & $0.0659^{* * *}$ & $0.066^{* * *}$ \\
\hline & $(5.24)$ & $(5.20)$ & $(4.24)$ & $(4.25)$ \\
\hline \multirow{2}{*}{ FAR } & $-0.0302^{*}$ & $-0.0273^{*}$ & $-0.0775^{* *}$ & $-0.0769^{* *}$ \\
\hline & $(-2.55)$ & $(-2.30)$ & $(-3.09)$ & $(-3.07)$ \\
\hline \multirow{2}{*}{ GAR } & $0.0595^{*}$ & $0.0615^{*}$ & $0.237^{* * *}$ & $0.233^{* * *}$ \\
\hline & $(2.00)$ & $(2.15)$ & $(3.35)$ & (3.32) \\
\hline \multirow{2}{*}{ Dwelling age } & $-0.0683^{* * *}$ & $-0.0671^{* * *}$ & $-0.133^{* * *}$ & $-0.133^{* * *}$ \\
\hline & $(-4.37)$ & $(-4.42)$ & $(-8.34)$ & $(-8.53)$ \\
\hline \multirow{2}{*}{ Slab type apartment } & $0.0587^{* * *}$ & $0.0606^{* * *}$ & $0.09^{* * *}$ & $0.094^{* * *}$ \\
\hline & $(3.33)$ & $(3.49)$ & $(4.09)$ & $(4.30)$ \\
\hline \multirow{2}{*}{ Finely decorated apartment } & & & $-0.0578^{*}$ & $-0.0577^{*}$ \\
\hline & & & $(-2.30)$ & $(-2.30)$ \\
\hline \multicolumn{5}{|l|}{ Facility Accessibility } \\
\hline \multirow{2}{*}{ Good accessibility to hospitals } & & & $-0.0159^{* * *}$ & $-0.0157^{* * *}$ \\
\hline & & & $(-3.63)$ & $(-3.63)$ \\
\hline \multicolumn{5}{|l|}{ Distance Attributes } \\
\hline \multirow{2}{*}{ Distance to city center } & $-0.4692^{* * *}$ & $-0.4719^{* * *}$ & $-0.6498^{* * *}$ & $-0.65^{* * *}$ \\
\hline & $(-17.96)$ & $(-19.16)$ & $(-19.92)$ & $(-19.88)$ \\
\hline \multirow{2}{*}{ Distance to nearest subway station } & $-0.0647^{* * *}$ & $-0.0638^{* * *}$ & $-0.11^{* * *}$ & $-0.109^{* * *}$ \\
\hline & $(-5.50)$ & $(-6.41)$ & $(-5.98)$ & $(-5.88)$ \\
\hline \multirow{2}{*}{ Distance to nearest rapid bus station } & -0.0183 & & 0.0119 & \\
\hline & $(-1.15)$ & & $(0.74)$ & \\
\hline \multicolumn{5}{|l|}{ Less than $5 \mathrm{~min}$ to nearest rapid bus station on foot } \\
\hline \multirow{2}{*}{$\begin{array}{l}\text { Less than } 10 \text { min but longer than } 5 \text { min to nearest } \\
\text { rapid bus station on foot }\end{array}$} & & $0.0521^{* *}$ & & -0.0244 \\
\hline & & $(2.37)$ & & $(-1.02)$ \\
\hline \multirow{2}{*}{$\begin{array}{l}\text { Longer than } 10 \mathrm{~min} \text { to nearest rapid bus station on } \\
\text { foot }\end{array}$} & & & & \\
\hline & & & & \\
\hline \multicolumn{5}{|l|}{ Constant } \\
\hline \multirow{2}{*}{ Constant } & $14.159^{* * *}$ & $14.04^{* * *}$ & $15.58^{* * *}$ & $15.68^{* * *}$ \\
\hline & $(71.54)$ & $(74.3)$ & $(52.86)$ & $(54.52)$ \\
\hline$N$ & 272 & 272 & 282 & 282 \\
\hline$R^{2}$ & 0.8273 & 0.8303 & 0.7453 & 0.7458 \\
\hline$B I C$ & -358.5 & -363.3 & -130.1 & -130.7 \\
\hline MSE & 0.1157 & 0.1147 & 0.1732 & 0.1731 \\
\hline Log-likelihood & 204.44 & 206.84 & 95.84 & 96.13 \\
\hline
\end{tabular}

t statistics in parentheses

${ }^{*} p<0.05,{ }^{* *} p<0.01,{ }^{* * *} p<0.001$ 
The model results showed that BRT had different impacts on houses along BRT1 and BRT3. Specifically, for pre-owned homes along BRT1, the prices were positively related to dwelling size, slab type, and GAR and were negatively related to dwelling age, distance to city center, distance to nearest subway station, and FAR. The results agreed with what was expected. Note that the absolute value of the estimate for each factor was smaller in BRT1 (see Table 3). Therefore, the pre-owned home prices along BRT1 were less sensitive to each factor than those along BRT3 in terms of both positive impacts and negative impacts.

For distance measures, straight distance from home to a BRT station was not significant in the model. However, when measured by dummy variables, the results showed that BRT had a significant impact on homes located within 5-10 minutes' walking distance to the nearest BRT station. It confirmed that a saturation point does exist. On average, property values for homes located within 5-10 minutes' walking distance to BRT stations were $5.35 \%$ higher than homes located in other zones $(\exp (0.0521)-1=0.0535)$.

For homes along BRT3, the number of dwellings in the neighborhood and having a roughcast apartment also showed negative impacts on property values. The impact of BRT3 on pre-owned home prices was mainly insignificant. Both the $F$ test and the LR test treated the proximity to BRT stations as a redundant variable. The final model showed that the farther away people lived from BRT3, the higher the home prices might be. In summary, unlike BRT1, BRT3 has little to no impact on pre-owned home values.

\section{Conclusion}

Overall, Beijing's BRT routes have different impacts on pre-owned home values. BRT1 did contribute to the increase in nearby pre-owned home values; however, the impact was nonlinear. It had a strong impact on properties with good accessibility to BRT1, but not too close. The values of homes located within 5-10 minutes' walking distance to BRT1 stations were $5.35 \%$ higher than those located closer to or further away from stations. Different from BRT1, BRT3 almost had no impact on surrounding home values.

The difference can be interpreted as follows:

- As discussed earlier, the average pre-owned home price along BRT3 was about 2,000 RMB higher than those near BRT1 (see Table 2). Studies (Cervero and Kang, 2011) also found that wealthier people were more likely to commute by private vehicle or subway instead of rapid bus. For them, the negative impact of noise and separated lanes taken by rapid buses may override the benefit of good accessibility to rapid bus stations.

- Homes along BRT3 were much closer to existing subway lines than those along BRT1 (Figure 1). Compared to subway, BRT was a much less attractive mode, especially when the city's subway was established much earlier and more comprehensively than the BRT system. All models in this study show that the accessibility to subway stations had a much more significant and more stable impact than accessibility to rapid bus stations. In other words, when subway is available, BRT has no advantages and its impact on home prices nearly vanishes. 
This research suffered from data limitation issues. Very limited built environment information was available for the selected samples. Further, cities in China usually do not provide complete and open accessible real estate data for general public. These limitations were major challenges for this research. Future studies need to include more real estate sales data and more detailed built environment characteristics around samples.

\section{References}

Cao, X., and J. A. Hough. 2012. "Hedonic Value of Transit Accessibility: An Empirical Analysis in a Small Urban Area." Journal of the Transportation Research Forum, 47.

Celik, H. M., and U. Yankaya. 2006. "The Impact of Rail Transit Investment on the Residential Property Values in Developing Countries: The Case of Izmir Subway, Turkey." Property Management, 24 (4): 369-382.

Cervero, R., and M. Duncan. 2004. "Neighbourhood Composition and Residential Land Prices: Does Exclusion Raise or Lower Values?" Urban Studies, 41 (2): 299-315.

Cervero, R., and C.-D. Kang. 2011. "Bus Rapid Transit Impacts on Land Uses and Land Values in Seoul, Korea." Transport Policy, 18 (1): 102-116.

Cervero, R., and J. Landis. 1997. "Twenty Years of the Bay Area Rapid Transit System: Land Use and Development Impacts." Transportation Research Part A: Policy and Practice, 31 (4): 309-333.

Garrett, T. A. 2004. "Light Rail Transit in America: Policy Issues and Prospects for Economic Development." Unpublished manuscript, Federal Reserve Bank of St. Louis, Research Department.

Gatzlaff, D. H., and M. T. Smith. 1993. "The Impact of the Miami Metrorail on the Value of Residences Near Station Locations." Land Economics: 54-66.

Haider, M., and E. J. Miller. 1995. "Effects of Transportation Infrastructure and Location on Residential Real Estate Values Application of Spatial Autoregressive Techniques." Transportation Research Record, 1722: 1-8.

Knaap, G. J., C. Ding, and L. D. Hopkins. 2001. “Do Plans Matter?: The Effects of Light Rail Plans on Land Values in Station Areas." Journal of Planning Education and Research, 21 (1): 32-39.

Knoblauch, R. L., M. T. Pietrucha, and M. Nitzburg. 1996. "Field Studies of Pedestrian Walking Speed and Start-Up Time." Transportation Research Record, 1538 (1): 27-38.

Landis, J., S. Guhathakurta, and M. Zhang. 1994. "Capitalization of Transit Investments into Single-Family Home Prices: A Comparative Analysis of Five California Rail Transit Systems." University of California Transportation Center.

Lee, D. A., D. L. Miller, and R. E. Skinner. 2007. TCRP Report 118: Bus Rapid Transit Practitioner's Guide. Transportation Research Board of the National Academies, Washington, DC. 
Levinson, H. S, S. Zimmerman, J. Clinger, and S. C. Rutherford. 2002. “Bus Rapid Transit: An Overview." Journal of Public Transportation, 5 (2): 1-30.

McMillen, D. P., and J. McDonald. 2004."Reaction of House Prices to a New Rapid Transit Line: Chicago's Midway Line, 1983-1999." Real Estate Economics, 32 (3): 463-486.

Munoz-Raskin, R. 2010. "Walking Accessibility to Bus Rapid Transit: Does It Affect Property Values? The Case of Bogotá, Colombia." Transport Policy, 17 (2): 72-84.

Palmquist, R. B. 1991. "Hedonic Methods: Measuring the Demand for Environmental Quality": 77-120.

Rodriguez, D. A., and C. H. Mojica. 2008. "Land Value Impacts of Bus Rapid Transit: The Case of Bogotá's TransMilenio." Land Lines.

Rodríguez, D. A., and F. Targa. 2004. "Value of Accessibility to Bogotá's Bus Rapid Transit System." Transport Reviews, 24 (5): 587-610.

Vuchic, V., E. C. Bruun, N. Krstanoski, Y. E. Shin, S. Kikuchi, P. Chakrobotry, and V. Perincherry. 2014. "The Bus Transit System: Its Underutilized Potential." http://trid.trb. org/view.aspx?id=405368, accessed March 6, 2014.

Vuchic, V. R. 2002. "Bus Semirapid Transit Mode Development and Evaluation. Journal of Public Transportation, 5 (2): 71-96.

Weinstein, B. L., T. L. Clower, F. Means, L. G. Gage, M. Pharr, G. Pettibon, and S. Gillis. 2014. "An Assessment of the DART LRT on Taxable Property Valuations and Transit Oriented Development." http://trid.trb.org/view.aspx?id=660484, accessed March 6, 2014.

Wright, L., and W. Hook, eds. 2007. Bus Rapid Transit Planning Guide. 3rd ed. New York: The Institute for Transportation and Development Policy.

Yang, Y., and X. Feng Xiangzhao. 2010. "Policy Options for Sustainable Development in Urban Transport: Analysis of Energy Consumption and Environmental Benefit Influenced by Different Transport Policies in Beijing." Chinese Journal of Population Resources and Environment, 8 (4): 26-36.

\section{About the Authors}

HAo Pang (vicph2011@utexas.edu) is a Ph.D. student in the Community of Regional Planning Program at the University of Texas at Austin with specialization in transportation and land use planning. His interests include public transportation, New Urbanism practices in transportation planning, travel demand modeling, and sustainable land use planning.

JUNFENG JIAO (jjiao@austin.utexas.edu) is an Assistant Professor in Community of Regional Planning at the University of Texas at Austin. He received his Ph.D. in urban planning and M.Sc. in transportation engineering from the University of Washington. His research interests include public transportation, transportation modeling, GIS and GPS applications, and public health. 